\title{
The ability of COVID-19 patients' blood to coagulate after withdrawn to EDTA tube: A case report
}

\section{EDTA tüpüne çekildikten sonra COVID-19 hastalarının kanının pıhtılaşma yeteneği: Olgu sunumu}

\author{
Hashim Talib Hashim
}

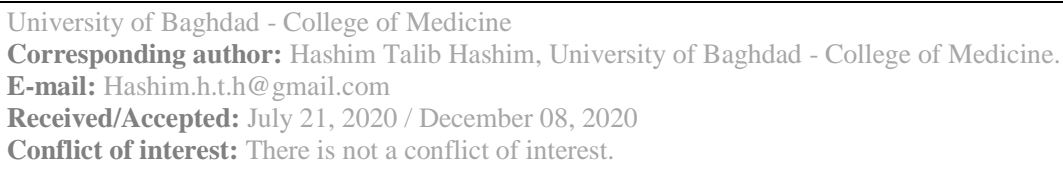

\section{SUMMARY}

In the same family, the SARS-COV-2 virus is more virulent than the other virus, and it is known in many patients that it causes extreme symptoms ranging from high-grade fever, cough, dyspnea, to gastrointestinal and hematological symptoms.

The extreme inflammatory state secondary to Covid-19 may lead to a severe imbalance in hemostasis as found recently in a condition of disseminated intravascular coagulation (DIC) and consumption coagulopathy, identified as decreased platelet count, increased fibrin or fibrinogen and red blood cells destruction which growing ferritin.

The virus has the ability to cause red blood cell hemolysis even if the blood is inside the EDTA tube, which reflects the virulent traits of the virus and its non-understandable pathogenesis, which is still suspected.

The damage caused by the tissue may increase the level of lactic acid dehydrogenase and may be an indicator of the amount of damage caused by the disease in the organs of the body.

Keywords: COVID-19; blood coagulation; EDTA tube; ferritin; Lactic Acid Dehydrogenase.
Hashim Talib Hashim

ORCID IDs of the authors: H.T.H. 0000-0001-6155-7302

\section{ÖZET}

Aynı ailede SARS-COV-2 virüsü diğer virüse göre daha öldürücüdür ve birçok hastada yüksek dereceli ateş, öksürük, nefes darlığından gastrointestinal ve hematolojik semptomlara kadar aşırı semptomlara neden olduğu bilinmektedir. Covid-19'a ikincil aşırı inflamatuar durum, son zamanlarda yaygın intravasküler pıhtılaşma (DIC) ve azalmış trombosit sayısı, artmış fibrin veya fibrinojen ve kırmızı kan hücrelerinin yıkımı olarak tanımlanan tüketim koagülopatisinde olduğu gibi hemostazda ciddi bir dengesizliğe yol açabilir büyüyen ferritin.

Virüs, kan EDTA tüpünün içinde olsa bile kırmızı kan hücresi hemolizine neden olma kabiliyetine sahiptir, bu da virüsün virülan özelliklerini ve hala şüphelenilen anlaşılmaz patogenezini yansıtır.

Dokunun neden olduğu hasar, laktik asit dehidrojenaz seviyesini artırabilir ve vücudun organlarında hastalığın neden olduğu hasar miktarının bir göstergesi olabilir.

Anahtar sözcükler: COVID-19; kan pıhtılaşması; EDTA tüpü; ferritin; Laktik Asit Dehidrojenaz. 


\section{INTRODUCTION}

COVID-19 disease that causes severe acute respiratory diseases than SARS-1 is becoming more prevalent worldwide and spreads very rapidly, with high mortality rates among patients in those countries with high infection rates that are more susceptible to infection due to lack of adequate facilities, in addition to physicians and health workers.

SARS-COV-2 virus is more virulent in the same family than the other virus, and many patients understand that it causes serious symptoms ranging from high-grade fever, cough, dyspnea to gastrointestinal symptoms and hematological manifestations. ${ }^{1}$

This novel strain is highly transmissible and up to $16 \%$ of hospitalized cases have reported serious illnesses. More than 600,000 deaths have been confirmed and death rates are rising. ${ }^{2}$

COVID-19 Hospitalized patients, especially those with extreme respiratory or systemic symptoms, fall within the chronically ill medical population, which are at high risk of venous thromboembolism. ${ }^{2}$

Severe inflammatory condition secondary to Covid-19 may lead to a severe imbalance in hemostasis as recently identified in the condition of disseminated intravascular coagulation (DIC) and intake coagulopathy defined as decreased platelet count, increased fibrin or fibrinogen and increased ferritin-borne red blood cell destruction ${ }^{3,4}$

Not all patients with COVID-19 develop a coagulation state, and even if it is developed, it differs from one patient to another and may be mild to severe. ${ }^{5}$

At the baseline and during the course of the disease, careful assessment of laboratory indices may assist clinicians in developing a tailored approach to treatment and provide intensive care to those most in need at an early stage. ${ }^{6}$

Preventive measures for thromboprophylaxis and early identification of potentially lethal complications, including DIC, will improve patient outcomes and likely reduce the overall death rate among infected patients without significant comorbidities. ${ }^{7}$

Dysregulation of the urokinase pathway and other related prothrombotic genes also involved the pathogenesis of coagulation disorders associated with SARS-CoV-1. In a mouse model infected with SARS-CoV-1, expression of procoagulant genes (thrombin, VII, XI, XII), expression of plasminogen activators (PLAU, PLAT) and dysregulation of the urokinase pathway have been associated with fatal SARS-CoV-1 infection. ${ }^{8}$

\section{CASE REPORT}

A 60-year-old obese male with headache, highgrade fever $(39.5 \mathrm{C})$, chills, persistent dry cough and mild dyspnea. It also has mild gastrointestinal symptoms of diarrhea and abdominal distension. These symptoms have been developed for three days prior to admission.

On the examination of the chest, he had decreased breathing sounds in the base of both lungs with wheezing.

The patient was sent for laboratory assessment of complete blood count (CBC) and chest $\mathrm{x}$-ray.

After 30 minutes, the laboratory assistant arrived with the patient's EDTA tube, which showed a coagulation of the patient's blood despite having anticoagulation material (shown in Figure 1). 


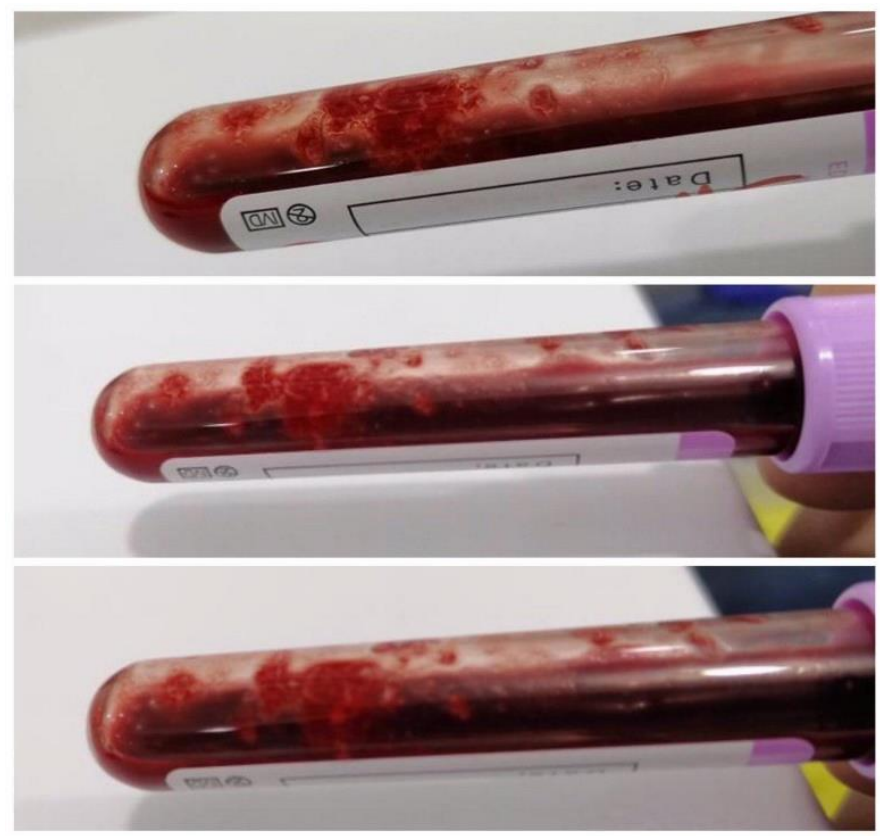

Figure 1: The EDTA tube of the patient.

Subsequently, the x-ray was obtained for the patient as shown in Figure (2), showing the appearance of ground glass and severe pneumonia in both lungs.

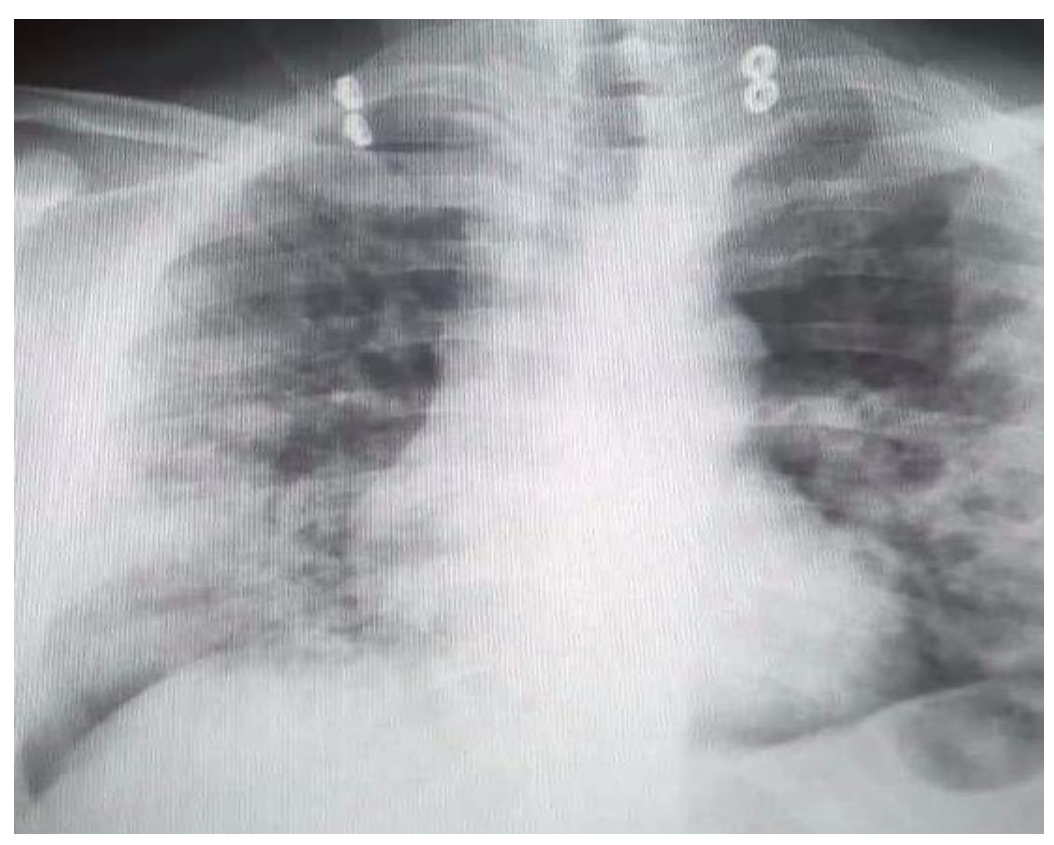

Figure 2: The PA chest x-ray of the patient.

After asking the patient for more details, he said he was in a marriage party in his living area a week ago.

Controlled hypertension, but not diabetic or any other chronic disease.
The results of his lab are shown in Table (1), which shows an increase in the level of ferritin that indicated hemolysis and destruction of red blood cells. 


\begin{tabular}{|l|c|}
\hline \multicolumn{2}{|c|}{ Table (1): The lab results of the patient } \\
\hline White Blood Cells (WBC) & The level \\
\hline Neutrophils & $6.99 * 10^{9} / \mu \mathrm{L}$ \\
\hline Eosinophil & $70.3 \%(\mathrm{IG} \mathrm{Band})$ \\
\hline Basophils & $12.2 \%$ \\
\hline Lymphocytes & $1.17 \%$ (DFLT (NE)) \\
\hline Monocytes & $5.61 \%(\mathrm{NRBC} / \mathrm{RRBC})$ \\
\hline Red Blood Cells (RBC) & $4.36 * 10^{12} / \mu \mathrm{L}$ \\
\hline Hemoglobin (HGB) & $13.2 \mathrm{~g} / \mathrm{dL}$ \\
\hline Hematocrit (HCT) & $37.9 \%$ \\
\hline Mean Corpuscular volume (MCV) & $87.1 \mathrm{fL}$ \\
\hline Mean Corpuscular Hemoglobin (MCH) & $30.3 \mathrm{pg}$ \\
\hline Mean Corpuscular Hemoglobin Concentration (MCHC) & $34.8 \mathrm{~g} / \mathrm{dL}$ \\
\hline Red Cells Distribution Width (RDW) & $11.9 \%$ \\
\hline Platelets (PLT) & $34.8 * 10^{9} / \mu \mathrm{L}$ \\
\hline Mean Platelets Volume (MPV) & $9.56 \mathrm{fL}$ \\
\hline Ferritin & $2000 \mathrm{ng} / \mathrm{mL}$ \\
\hline Lactic Acid Dehydrogenase (LDH) & $596 \mathrm{U} / \mathrm{L}$ \\
\hline
\end{tabular}

The patient was diagnosed with COVID-19 disease and sent to the City Isolation Hospital after receiving an RT-PCR confirmation test.

The patient's follow-up was very difficult in isolation, but he was confirmed with the disease and began taking $\mathrm{O} 2$ mask supportive treatment for his intermittent dyspnea episodes.

\section{DISCUSSION}

The case is very suspected, especially with fever and abnormal breathing. The $\mathrm{x}$-ray approved the suspicion and increased the chance of diagnosis, but the protocol in the country is based on the results of the RT-PCR confirmation only so that the definitive diagnosis was made in an isolated hospital.

The most interesting and focused case was the coagulation that occurred in the EDTA tube, reflecting the ability of the virus and its virulence to attack the blood, particularly the RBCs that caused their hemolysis, which is why the level of ferritin was very high (see Table 1).
Neutrophils have been elevated to the level of defense against infections that support diagnosis.

The high level of LDH (596 U / L) is an indication of tissue damage that may reflect lung tissue or other tissue because SARS-COV-2 is a very virulent virus that attacks all systems and is considered by many authors and physicians to cause systemic disease because it includes many systems and organs at the same time. ${ }^{5}$

This virus has a virulence trait that allows it to attack many cells in the same time which are similar in the receptors or the constituents. This may explain its ability to attack lung cells, hematological cells and GIT cells at the same time as well as kidney cells, since many studies show its ability to produce renal symptoms in many patients, such as urinary frequency which was attributed (the opinion of the author) to viral cystitis caused by the same virus. ${ }^{9}$ 


\section{Conflict of interest:}

- I declare that I have no conflict of interest.

- I declare that IO have no source of funding received.

- Patient consent paper was signed by the patient himself.

- Ethical approval was obtained from the ethical committee of the university of B.

\section{REFERENCES}

1. Hassan S, Sheikh F, Jamal S, Ezeh J, Akhtar A. Coronavirus (COVID-19): A Review of Clinical Features, Diagnosis, and Treatment. Cureus. 2020; Published online 2020 Mar 21. DOI: $10.7759 /$ cureus.7355.

2. Giannis D, Ziogas I, Gianni P. Coagulation disorders in coronavirus infected patients: COVID-19, SARS-CoV-1, MERS-CoV and lessons from the past. Journal of Clinical Virology. 2020;127:104362. Published online $2020 \quad$ April 9. https://doi.org/10.1016/j.jcv.2020.104362

3. Panigada M, Bottino N, Tagliabue P, Grasselli $\mathrm{G}$, Novembrino $\mathrm{C}$, Chantarangkul $\mathrm{V}$ et al. Hypercoagulability of COVID-19 patients in Intensive Care Unit. A Report of Thromboelastography Findings and other Parameters of Hemostasis. Journal of Thrombosis and Haemostasis. 2020; Published online: 17 April 2020. https://doi.org/10.1111/jth.14850.

4. Jose R, Manuel A. COVID-19 cytokine storm: the interplay between inflammation and coagulation. The Lancet Respiratory Medicine. 2020;8(6):e46-e47. Published online April 27, 2020. DOI: https://doi.org/10.1016/S22132600(20)30216-2

5. Ranucci M, Ballotta A, Di Dedda U, Bayshnikova E, Dei Poli M, Resta M et al. The procoagulant pattern of patients with COVID19 acute respiratory distress syndrome. Journal of Thrombosis and Haemostasis. 2020; Published online: 17 April 2020. https://doi.org/10.1111/jth.14854.

6. Spiezia L, Boscolo A, Poletto F, Cerruti L, Tiberio I, Campello E et al. COVID-19Related Severe Hypercoagulability in Patients Admitted to Intensive Care Unit for Acute Respiratory Failure. Thrombosis and Haemostasis. 2020;120(06):998-1000. Published online 2020 Apr 21. DOI: 10.1055/s-0040-1710018.

7. Connors J, Levy J. Thromboinflammation and the hypercoagulability of COVID-19. Journal of Thrombosis and Haemostasis. 2020; Published online: 17 April 2020. https://doi.org/10.1111/jth.14849.

8. Levi M, Thachil J, Iba T, Levy J. Coagulation abnormalities and thrombosis in patients with COVID-19. The Lancet Haematology. 2020;7(6):e438-e440. Published online 2020 May $\quad 11$ DOI: $10.1016 / S 2352-$ 3026(20)30145-9

9. Mumm J, Osterman A, Ruzicka M, Stihl C, Vilsmaier $\mathrm{T}$, Munker $\mathrm{D}$ et al. Urinary Frequency as a Possibly Overlooked Symptom in COVID-19 Patients: Does SARS-CoV-2 Cause Viral Cystitis? European Urology. 2020; Published online: 19 April 2020. DOI: https://doi.org/10.1016/j.eururo.2020.05.013.

10. Pei G, Zhang Z, Peng J, Liu L, Zhang C, Yu C et al. Renal Involvement and Early Prognosis in Patients with COVID-19 Pneumonia. Journal of the American Society of Nephrology. 2020;31(6):1157-1165. Published online: 31 June 2020. DOI: https://doi.org/10.1681/ASN.2020030276. 